\title{
$\mathrm{Sn}-8 \mathrm{Zn}-3 \mathrm{Bi}$ はんだと Ni/Au めっき電極を用いた CSP 接合部の界面組織と接合信頼性*1
}

\author{
山口 敦 史 $^{1}$ \\ 古 澤 彰 男 $^{1}$ \\ 西田一人 1 \\ 岩西宏昭 2 ,*2 \\ 北条隆志 $2, * 3$ \\ 十河陽介 ${ }^{2, * 4}$ \\ 廣瀬明 夫 $^{2}$ \\ 小林紘二郎 2
}

1松下電器産業株式会社

2 大阪大学大学院工学研究科

J. Japan Inst. Metals, Vol. 69, No. 1 (2005), pp. 132-138

(C) 2005 The Japan Institute of Metals

\section{Interfacial Reaction Layer and Reliability of CSP Solder Joints using Sn-8Zn-3Bi Solder and Ni/Au Plating Pad}

Atsushi Yamaguchi ${ }^{1}$, Akio Furusawa ${ }^{1}$, Kazuto Nishida ${ }^{1}$, Hiroaki Iwanishi' ${ }^{2}{ }^{* 2}$, Takashi $\mathrm{Hojo}^{2, * 3}$, Yosuke Sogo ${ }^{2, * 4}$, Akio Hirose ${ }^{2}$ and Kojiro F. Kobayashi ${ }^{2}$

${ }^{1}$ Matsushita Electric Industrial Co., Ltd., Kadoma 571-8502

${ }^{2}$ Graduate School of Engineering, Suita 565-0871

In order to investigate the use of $\mathrm{Sn}-8 \mathrm{Zn}-3 \mathrm{Bi}$ solder as a potential substitute for $\mathrm{Sn}-\mathrm{Pb}$ solder, which has lower melting point than $\mathrm{Sn}-\mathrm{Ag}$ family solder, we studied interfacial microstructure and mechanical properties of CSP joints with various thickness of $\mathrm{Au}$ and $\mathrm{Ni}$ plated on $\mathrm{Cu}$ pad compared with $\mathrm{Cu}$ pad. Joint strength and other mechanical properties were evaluated in relation to reflow peak temperature. The combination of Au plating thickness of $0.05 \mu \mathrm{m}$ and reflow peak temperature of $498 \mathrm{~K}$ resulted in the best joint reliability both as soldered and after aging treatment. The joint had thin $\mathrm{Ni}_{3} \mathrm{Sn}_{4}$ type interfacial reaction layer that included $\mathrm{Cu}$ and $\mathrm{Zn}$ between the solder and the Ni plating. This interfacial microstructure caused to improve the joint strength.

(Received August 11, 2004; Accepted November 22, 2004)

Keywords: lead-free solder, nickel/gold plating, chip size package(CSP), interfacial reaction layer, joint reliability

\section{1. 緒言}

近年, 携帯機器の小型化·軽量化に伴い, 実装基板の高密 度化が望まれている. チップ部品は 1005 タイプ $(1 \mathrm{~mm} \times$ $0.5 \mathrm{~mm}$ サイズ)から 0603 タイプ $(0.6 \mathrm{~mm} \times 0.3 \mathrm{~mm}$ サイズ $)$ へと移行し, 実装時の部品間距離は狭まる傾向にある. また, $\mathrm{IC}$ パッケージの小型・薄型化も進み, 従来の $\mathrm{QFP}(\mathrm{Quad}$ Flat Package) から BGA (Ball Grid Array)や CSP (Chip Size Package)へと移行して扣り，そのBGA，CSPに拈ても， $0.8 \mathrm{~mm}$ ピッチから更に狭ピッチなもの採用へと進んでい る1).

また，世界的な環境問題に対する関心の高まりから，鉛フ リーはんだ材料の実用化が進んで抢り, 熱的・機械的特性の バランスがとれた $\mathrm{Sn}-\mathrm{Ag}-\mathrm{Cu}$ はんだが $\mathrm{Sn}-\mathrm{Pb}$ 共晶はんだに

\footnotetext{
*1 Mater. Trans. 45(2004) 134-740 に掲載

*2 大阪大学大学院生, 現在 : 本田技研工業侏 (Graduate Student, Osaka University, Present address: Honda Motor Co., Ltd.)

*3 大阪大学大学院生, 現在 : 関西電力秼 (Graduate Student, Osaka University, Present address: Kansai Electric Power Co. Inc.)

${ }^{* 4}$ 大阪大学大学院生 (Graduate Student, Osaka University)
}

代替する最有力候補となりつつある ${ }^{2,3)}$. しかし, $\mathrm{Sn}-\mathrm{Ag}-\mathrm{Cu}$ はんだは, その融点の高さのため, 部品耐熱温度によるリフ ロー温度プロファイルの制約からすべてのリフロープロセス 適応商品に対して対応することは困難である.このような中, $\mathrm{Sn}-\mathrm{Zn}-\mathrm{Bi}$ はんだは, $\mathrm{Sn}-\mathrm{Pb}$ 共晶はんだに融点が近く部品の 熱損傷が少ない低融点はんだとして期待されている2). しか し, $\mathrm{Zn}$ の $\mathrm{Cu}$ との強い反応性から $\mathrm{Cu}$ との界面に従来とは異 なる $\mathrm{Cu}-\mathrm{Zn}$ の反応層を形成し, 高温下での接合特性の劣化 が生じる ${ }^{4-6)}$. そこで, 基板電極の表面処理として Ni/Au め っきを用いると, $\mathrm{Sn}-\mathrm{Zn}-\mathrm{Bi}$ はんだ接合界面の $\mathrm{Cu}-\mathrm{Zn}$ 反応層 の生成を防止でき，既にそれを用いた実用化事例が報告され ている7).しかし，その接合部の組織と継手特性について は，十分明らかになっていない。

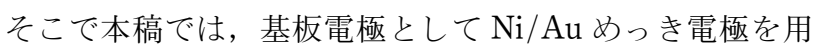
いた $\mathrm{Sn}-\mathrm{Zn}-\mathrm{Bi}$ はんだの CSP 接合部の組織と継手特性の関 係を明らかにすることにより，実用化に向けためっき構成， プロセス条件の指針を見出すため, $\mathrm{Sn}-\mathrm{Zn}-\mathrm{Bi}$ はんだによる $\mathrm{Ni} / \mathrm{Au}$ めっき電極上の CSP 接合部の継手特性について, Cu 電極上の CSP 接合部の継手特性と比較し, その接合部の界 面組織と機械的特性について調べ，その適正リフロープロフ ァイルについて検討した. 
Table 1 Basic physical properties of $\mathrm{Sn}-\mathrm{Zn}-\mathrm{Bi}$ solder.

\begin{tabular}{|c|c|c|c|c|c|c|c|c|c|c|}
\hline & \multicolumn{6}{|c|}{ Alloy composition (mass\%) } & \multicolumn{2}{|c|}{ Melting temperature $\left({ }^{\circ} \mathrm{C}\right)$} & \multirow{2}{*}{$\begin{array}{l}\text { Tensile strength } \\
\left(\mathrm{kgf} / \mathrm{mm}^{2}\right)\end{array}$} & \multirow{2}{*}{$\underset{(\%)}{\text { Elongation }}$} \\
\hline & $\mathrm{Sn}$ & $\mathrm{Ag}$ & $\mathrm{Bi}$ & $\mathrm{Pb}$ & $\mathrm{Cu}$ & $\mathrm{Zn}$ & Solidus & Liquidus & & \\
\hline $\mathrm{Sn}-\mathrm{Zr}-\mathrm{Bi}$ & Bal. & & 3 & & & 8 & 187 & 197 & 7.1 & 23 \\
\hline $\mathrm{Sn}-\mathrm{Ag}-\mathrm{Cu}$ & Bal. & 3 & & & 0.5 & & 219 & 217 & 3.6 & 38 \\
\hline $\mathrm{Sn}-\mathrm{Pb}$ & Bal. & & & 37 & & & 183 & 183 & 4.3 & 32 \\
\hline
\end{tabular}

Passivation Polyimide Redistribution Line

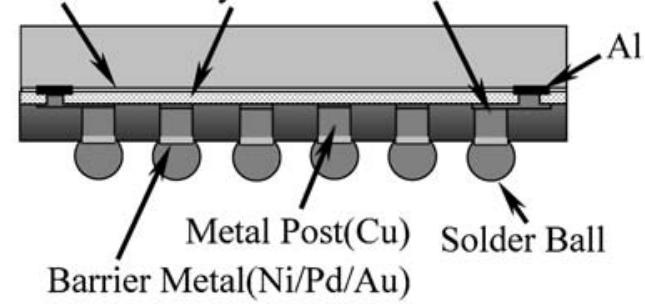

Fig. 1 CSP structure.

Table 2 CSP specification

\begin{tabular}{llc}
\hline \multicolumn{1}{c}{ Items } & Specifications \\
\hline CSP & Size $(\mathrm{mm})$ & $8.97 \times 8.97 \times 0.57$ \\
& Ball composition (mass\%) & $\mathrm{Sn}-3 \mathrm{Ag}-0.5 \mathrm{Cu}$ \\
& $\mathrm{Sn}-37 \mathrm{~Pb}$ \\
& Ball diameter $(\mathrm{mm})$ & 0.32 \\
Cu post diameter $(\mathrm{mm})$ & 0.23 \\
Pitch $(\mathrm{mm})$ & 0.5 \\
Number of balls & 240 \\
\hline
\end{tabular}

Table 3 PCB specification.

\begin{tabular}{lll}
\hline & \multicolumn{1}{c}{ Items } & Specifications \\
\hline Substrate & Material & FR-4 \\
& Size $(\mathrm{mm})$ & $127 \times 22 \times 0.8$ \\
& Pad diameter $(\mathrm{mm})$ & 0.3 \\
& Pad structure & $\mathrm{Cu}$ \\
& & $\mathrm{Cu} / \mathrm{Ni} / \mathrm{Au}$ \\
\hline
\end{tabular}

\section{2. 実 験 方 法}

\section{1 供試材料}

実装部品は $0.5 \mathrm{~mm}$ ピッチの CSP を用い，はんだ材に $\mathrm{Sn}-8 \mathrm{Zn}-3 \mathrm{Bi}$ はんだペースト, 部品電極に $\mathrm{Sn}-3 \mathrm{Ag}-0.5 \mathrm{Cu}$ は んだボールを用いた．基板は FR-4 基板を用い，基板表面処 理として $\mathrm{Cu}$ 耐熱プリフラックス処理および $\mathrm{Cu}$ に無電解 $\mathrm{Ni}$ $(5 \mu \mathrm{m}) / \mathrm{Au}$ めっきを施し，Au㴟を $0.05 \mu \mathrm{m}$ 抢よび $0.5 \mu \mathrm{m}$ と変化させた。な打, リファレンスとして, Sn$37 \mathrm{~Pb}$ はんだペーストを用い, 部品電極としては $\mathrm{Sn}-37 \mathrm{~Pb}$ はんだボールを用いた. Table 1 に各はんだの特性を示す.

Fig. 1, Table 2, Table 3 にそれぞれ CSP パッケージの模式 図，その仕様抢よび基板の仕様を示す。また，Fig. 2 にボー 儿接合部単点強度評価用実装の模式図を示す。

\section{2 ソルダリング条件}

Table 4 にリフローソルダリング条件を示す． Sn-8Zn-

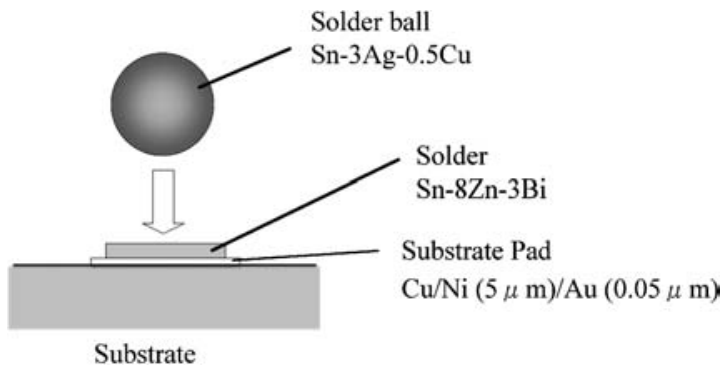

Fig. 2 Schematic illustration of ball pull test sample.

Table 4 Soldering condition.

\begin{tabular}{|c|c|c|c|c|}
\hline Sample name & Solder paste & Solder ball & $\begin{array}{l}\text { Reflow peak } \\
\text { temperature }\end{array}$ & $\begin{array}{c}\text { PCB pad } \\
\text { plating }\end{array}$ \\
\hline SZB-Cu-483 & \multirow{5}{*}{$\mathrm{Sn}-8 \mathrm{Zn}-3 \mathrm{Bi}$} & \multirow{5}{*}{$\mathrm{Sn}-3 \mathrm{Ag}-0.5 \mathrm{Cu}$} & \multirow[b]{2}{*}{$483 \mathrm{~K}$} & $\mathrm{Cu}$ \\
\hline SZB-Au0.05-483 & & & & $\begin{array}{c}\mathrm{Cu} / \mathrm{Ni}-\mathrm{Au} \\
(0.05 \mu \mathrm{m})\end{array}$ \\
\hline SZB-Au0.05-503 & & & $503 \mathrm{~K}$ & $\begin{array}{c}\mathrm{Cu} / \mathrm{Ni} / \mathrm{Au} \\
(0.05 \mu \mathrm{m})\end{array}$ \\
\hline SZB-Au0.5-483 & & & $483 \mathrm{~K}$ & $\begin{array}{c}\mathrm{Cu} / \mathrm{Ni} / \mathrm{Au} \\
(0.5 \mu \mathrm{m})\end{array}$ \\
\hline SZB-Au0.5-503 & & & $503 \mathrm{~K}$ & $\underset{(0.5 \mu \mathrm{m})}{\mathrm{Cu} / \mathrm{Ni} / \mathrm{Au}}$ \\
\hline $\mathrm{SP}-\mathrm{Cu}-483$ & \multirow[b]{2}{*}{$\mathrm{Sn}-37 \mathrm{~Pb}$} & \multirow[b]{2}{*}{$\mathrm{Sn}-37 \mathrm{~Pb}$} & \multirow[b]{2}{*}{$483 \mathrm{~K}$} & $\mathrm{Cu}$ \\
\hline SP-Au0.05-483 & & & & $\begin{array}{l}\mathrm{Cu} / \mathrm{Ni} / \mathrm{Au} \\
(0.05 \mu \mathrm{m})\end{array}$ \\
\hline
\end{tabular}

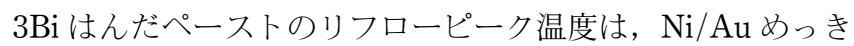
電極の継手は $\mathrm{Sn}-8 \mathrm{Zn}-3 \mathrm{Bi}$ の融点 $+10 \mathrm{~K}$ 以上 $(483 \mathrm{~K})$ と Sn$3 \mathrm{Ag}-0.5 \mathrm{Cu}$ はんだの融点 $+10 \mathrm{~K}$ 以上 $(503 \mathrm{~K})$ の 2 段階に変 化させた. また, $\mathrm{Cu}$ 電極を用いた継手のリフローピーク温 度は $503 \mathrm{~K}$ とした。 なお， $\mathrm{Sn}-\mathrm{Pb}$ ペーストのリフローピー ク温度を $483 \mathrm{~K}$ とした. Fig. 3 にリフロープロファイルを 示す.このとき, 融点以上の温度で $20 \mathrm{~s}$ 以上保持するとと もに，プリヒート温度を $403 \sim 423 \mathrm{~K}$ とし， $60 \pm 20 \mathrm{~s}$ 保持と した。また，リフロー雾囲気は大気で行った。

\section{3 高温放置試験}

長時間使用環境を想定した継手特性評価を行うために，ソ ルダリング後の CSP 抢よび強度評価用基板について高温放 置試験を行った。このとき保持温度は $398 \mathrm{~K}$, 保持時間は $1.8 \mathrm{Ms}, 3.6 \mathrm{Ms}, 5.4 \mathrm{Ms}$ とした.

\section{4 接合部組織観察および反応相の同定}

試料を基板に対して垂直方向にファインカッターを用いて 切断し, エメリ一紙 (\#2000) を用いて研磨し，その後ダイ ヤモンドペースト $(1 \mu \mathrm{m})$ を用いてバフ研磨することで接合 
部断面観察試料を作製した。作製した接合部断面を EPMA (Electron-probe Micro-analyzer JXA-8700 JEOL 製)，走査 型電子顕微鏡 (SEM : Scanning Electron Microscopy S-800 日立製)を用いて組織観察および反応層の同定を行った。ま た，継手接合部の詳細な界面組織観察には，収束イオンビー 厶加工装置 (FIB : Focus Ion Beam FB-2000A 日立製作所製) により接合部断面を切り出し, 得られた試料について透過型 電子顕微鏡 (TEM : Transmission Electron Microscope H3000 日立製作所製)により組織観察および反応層の同定を行 った.

\section{5 繰り返し曲げ試験}

ソルダリング後および高温放置後の試料についてパッケー ジレベルでの強度評価を行うために, Fig. 4 に示す繰り返し 曲げ試験を行い，CSP のすべての接合部を直列につないだ 回路が破断に至るまでの曲げ回数を破断寿命とした。なお， 曲げ変位は $1 \mathrm{~mm}$ とし, 曲げ速度は $1.67 \mathrm{~mm} / \mathrm{s}$ とした．測 定はそれぞれの条件について 4 試料とした。

\section{6 接合部強度試験}

継手接合部の機械的特性評価として, BGA 加熱式バンプ プル (HBP : Hot Bump Pull) 試験を行った. 試験は, 万能型 ボンドテスター(DAGE-SERIES-4000P DAGE 社製)を用

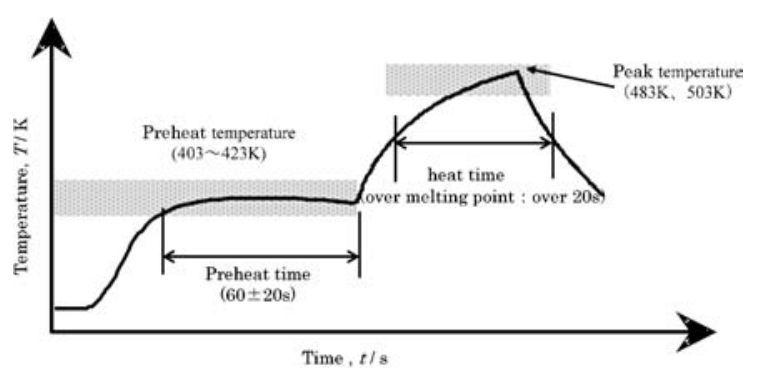

Fig. 3 Reflow Profile.

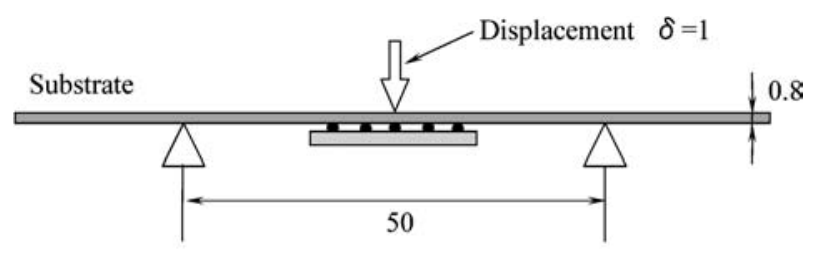

Bending Speed: $1.67 \mathrm{~mm} / \mathrm{s}$

Fig. 4 Bending fatigue test.

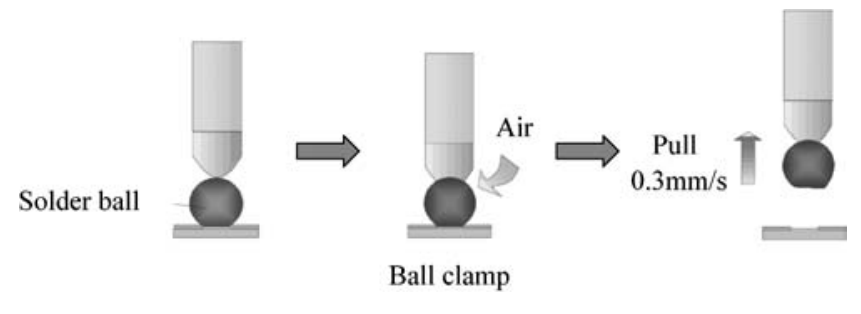

Fig. 5 Hot Bump Pull test.
いて，はんだ継手の破断荷重を測定した。引き上げ速度は $0.3 \mathrm{~mm} / \mathrm{s}$ とした. Fig. 5 に HBP 試験の模式図を示す.

\section{7 破面観察および破断経路の同定}

繰り返し曲げ試験, 加熱ボールプル試験後の試料につい て, 接合部組織と強度との関係を明確にするために 2.4 と同 様の方法で破面に対して垂直に切断, 研磨し EPMA を用い て破面垂直断面を観察し，破断経路について調べた。

\section{3. 実験結果および考察}

\section{1 繰り返し曲げ試験}

Fig. 6 に繰り返し曲げ試験の結果を示す. Sn-8Zn-3Bi は んだによる $\mathrm{Cu}$ 電極上の接合部の場合, 繰り返し曲げ寿命 は，初期に抢いては比較的良く，Sn-Pbはんだによる $\mathrm{Cu}$ 電 極上の接合部の高温保持後と同等であったが，高温保持時間 が長くなるとその寿命は劣化する傾向があった。これに対し て, $\mathrm{Ni} / \mathrm{Au}(0.05 \mu \mathrm{m})$ めっき電極を用いて $483 \mathrm{~K}$ でリフロー はんだ付けした接合部は，初期において $\mathrm{Cu}$ 電極上にはんだ 付けした場合よりもやや低寿命であった. しかし, 高温保持 するにつれて，寿命は回復した. $\mathrm{Ni} / \mathrm{Au}(0.05 \mu \mathrm{m})$ めっき電 極を用いてさらに高い $503 \mathrm{~K}$ でリフローはんだ付けした場 合，やや高温保持後に寿命の低下はあったが，最も高い寿命 であった. $\mathrm{Ni} / \mathrm{Au}(0.5 \mu \mathrm{m})$ めっき電極においては，はんだ付 け温度によらず低い寿命を示した。これらのことから Sn8Zn-3Bi はんだにより $\mathrm{Ni} / \mathrm{Au}$ めき電極上にはんだ付けす る場合, $\mathrm{Au}$ めっき厚さは, $0.05 \mu \mathrm{m}$ 程度に薄くつける必要 がある、また，より高温ではんだ付けを行うか，または高温 保持する方が寿命は延びると考えられる.

\section{2 界面組織反応}

\subsubsection{Cu 電極}

$\mathrm{Cu}$ 電極の場合の組織観察結果を Fig. 7 に示す。リフロー ソルダリング直後においてははんだと $\mathrm{Cu}$ の間で $\mathrm{Cu}_{5} \mathrm{Zn}_{8}$ 層 を形成していた8)。高温放置後においては， $\mathrm{Sn} に \mathrm{Cu}$ 電極が 侵食されており， $\mathrm{Cu}$ と $\mathrm{Sn}$ のあいだで $\mathrm{Cu}_{6} \mathrm{Sn}_{5}$ 層を形成して いた.

\section{$3.2 .2 \mathrm{Ni} / \mathrm{Au}$ めっき電極}

$\mathrm{Ni} / \mathrm{Au}(0.05 \mu \mathrm{m})$ めっき電極接合部の組織観察結果を Fig. 8 に示す. リフローピーク温度 $483 \mathrm{~K}$ の継手では, リフロー

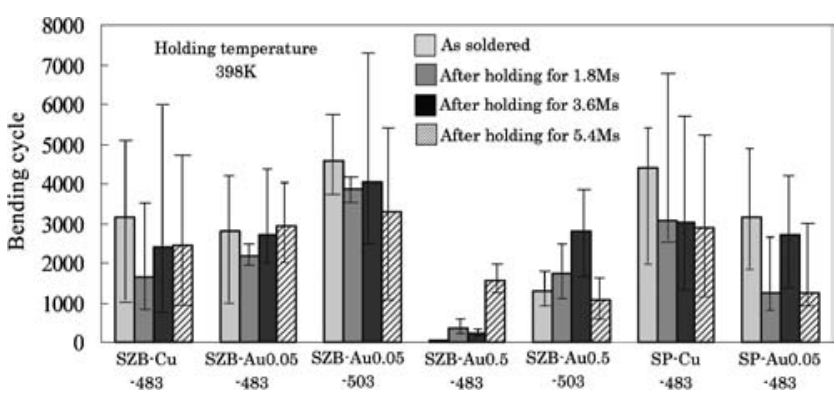

Fig. 6 Relationship between soldering condition and fatigue cycle. 


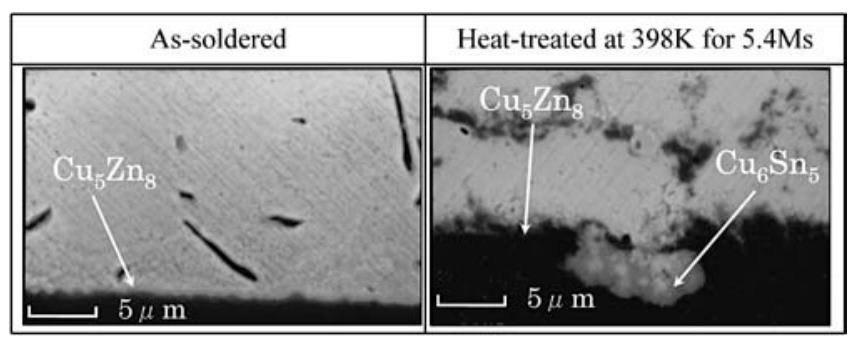

Fig. 7 BE images at joint interface of sample SZB-Cu-483.

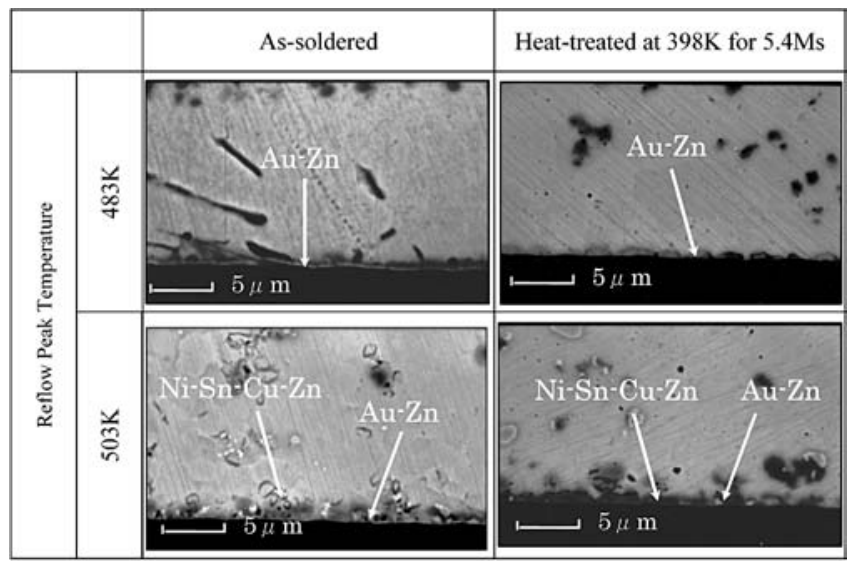

Fig. 8 BE images at joint interface of sample SZB-Au0.05483 and sample SZB-Au0.05-503.

直後には $\mathrm{Au}-\mathrm{Zn}$ 層を形成していた。リフローピーク温度 $503 \mathrm{~K}$ の継手では，接合界面に $\mathrm{Au}-\mathrm{Zn}$ 層は不均一に形成し，

$\mathrm{Ni}-\mathrm{Sn}-\mathrm{Cu}-\mathrm{Zn}$ からなる化合物層も形成していた。いずれの リフローピーク温度の場合でも高温放置後における組織の大 きな変化は見られなかった．いずれの界面反応層も極めて薄 かったのでEPMA 分析では，その組成を同定することがで きなかった，そこで，TEMによる観察を行った。

リフローピーク温度が $483 \mathrm{~K} て ゙ ， \mathrm{Au}$ めっき厚さ $0.05 \mu \mathrm{m}$ の継手に対する TEM による接合界面の詳細な組織観察結果 を Fig. 9 に示す．この結果から界面反応層は $\mathrm{AuZn}_{3}$ 層のみ が形成していた。このことから，リフロー温度が低い場合， $\mathrm{Au}$ めっきのはんだ中への溶解よりも $\mathrm{Au}$ めっきとZn の反 応が先行して進行し，界面に化合物層を形成したものと考え られる。

リフローピーク温度が $503 \mathrm{~K}$ のときの界面反応層を Fig. 10 に示す。リフロー温度が高い場合, $\mathrm{Au}-\mathrm{Zn}$ 層は $483 \mathrm{~K}$ の 場合よりも薄く，また，はんだ/ $\mathrm{Au}-\mathrm{Zn}$ 間で $(\mathrm{Ni}, \mathrm{Cu}$, $\mathrm{Zn})_{3} \mathrm{Sn}_{4}$ と考元られる化合物層を形成していた．また，その 界面にはP Pッチ層が形成していた。このことから， $\mathrm{Au}-$ Zn がはんだ中へ一部溶解するとともに，はんだ中の元素と $\mathrm{Ni}$ が相互拡散により, 界面の $\mathrm{Ni}$ を消費して界面反応が進行 したものと考えられる.リフローピーク温度が $483 \mathrm{~K}$ では P リッチ層が形成していないことからリフロー過程で形成す る $\mathrm{Au}-\mathrm{Zn}$ 層は，はんだと $\mathrm{Ni}$ の反応を防止するバリア層と して働いていると考えられる。これらの結果から，リフロー 温度は接合界面反応に大きく影響を与えているといえる.

次に $\mathrm{Ni} / \mathrm{Au}(0.5 \mu \mathrm{m})$ めっき電極の接合部の組織観察結果

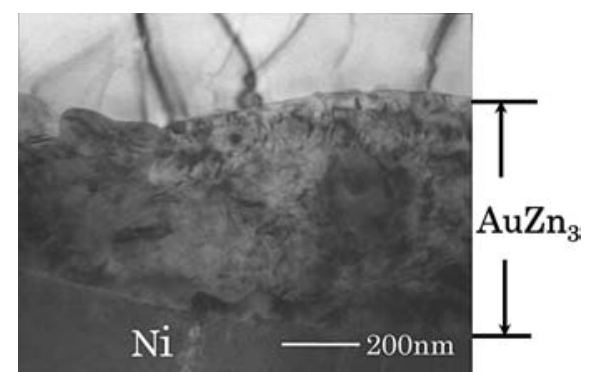

Fig. 9 TEM image at interfacial reaction layer of sample SZB-Au0.05-483.

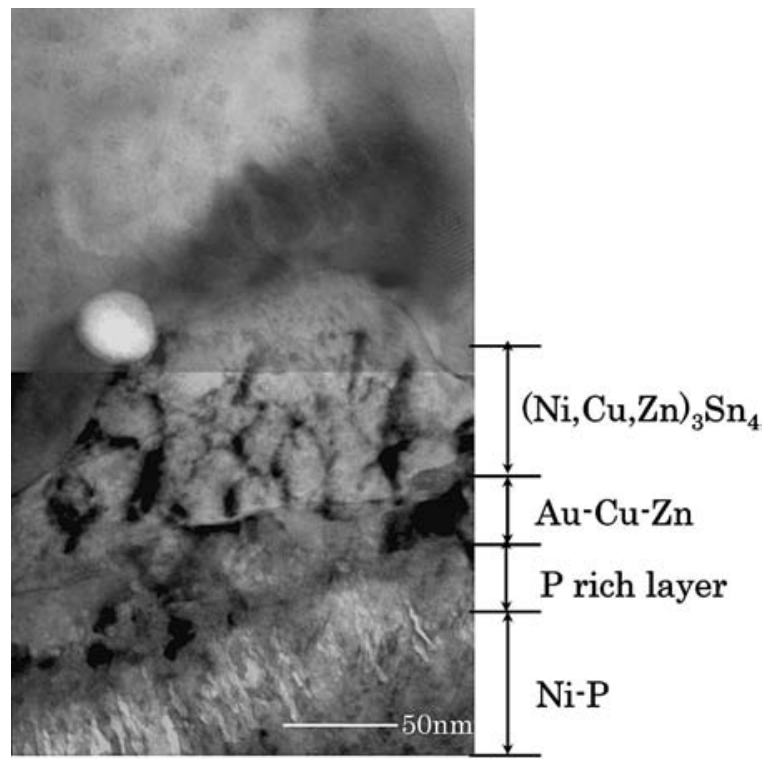

Fig. 10 TEM image at interfacial reaction layer of sample SZB-Au0.05-503.

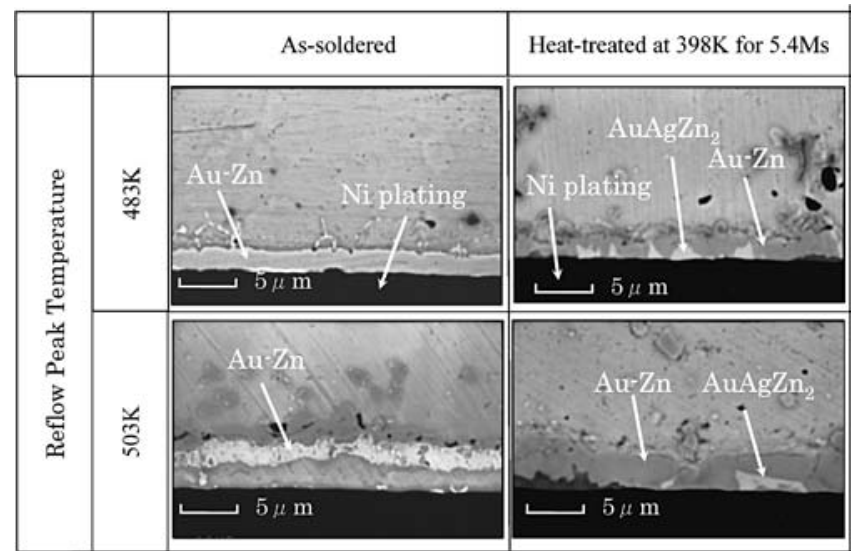

Fig. 11 BE images at joint interface of sample SZB-Au0.5483 and sample SZB-Au0.5-503.

をFig. 11 に示す． $483 \mathrm{~K}$ でリフローした場合は，接合界面

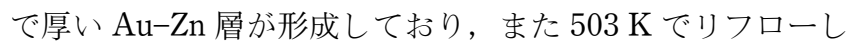
た継手については一部接合界面から離れた位置で厚い $\mathrm{Au}-$ Zn 層を形成していた，高温放置後においては，いずれのリ フローピーク温度に扔いても $\mathrm{Au}-\mathrm{Zn}$ の反応層中で $\mathrm{Ag}$ の濃 度が増加して抢り，局所的に $\mathrm{Ag}$ が濃化した $\mathrm{AuAgZn}_{2}$ 層を 
形成していた．より高いリフローピーク温度である $503 \mathrm{~K}$ に抢いて，Au-Zn 層が接合界面から剥離したのは，Au-Zn 層が，はんだ中へ溶解・拡散したためであると考えられる. これらのことから，Auめっきが $0.5 \mu \mathrm{m}$ のように厚い場 合, 繰り返し曲げ寿命結果を踏をえると, リフローピーク温 度が $483 \mathrm{~K}$ のように低いと界面の反応性が低いため界面強 度が低く，リフローピーク温度が $503 \mathrm{~K}$ のように高くて も，界面剥離が生じ，寿命が低下するといえる。

\section{3 破断経路}

\subsection{1 $\mathrm{Cu}$ 電極}

$\mathrm{Cu}$ 電極の継手についての破断経路を Fig. 12 に示す.リ フロー直後では破壊は，はんだ中で進展しており，界面強度 は十分であったが，高温放置試験により $\mathrm{Cu}_{6} \mathrm{Sn}_{5}$ 層が形成さ れ，破壊の起点もしくは伝播経路となって抢り，この高温放 置に伴う $\mathrm{Cu}_{6} \mathrm{Sn}_{5}$ 層の形成が継手強度劣化の原因と考えられ る.

\subsubsection{Ni/Auめっき電極}

$\mathrm{Ni} / \mathrm{Au}(0.05 \mu \mathrm{m})$ めっき電極で, $483 \mathrm{~K}$ でリフローした接

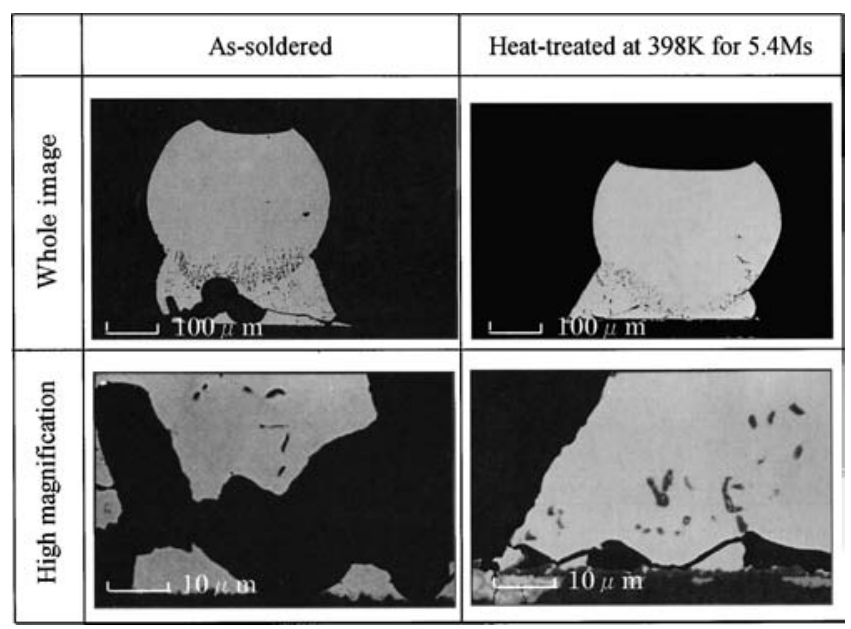

Fig. 12 Crack path of sample SZB-Cu-483 after bending fatigue test.

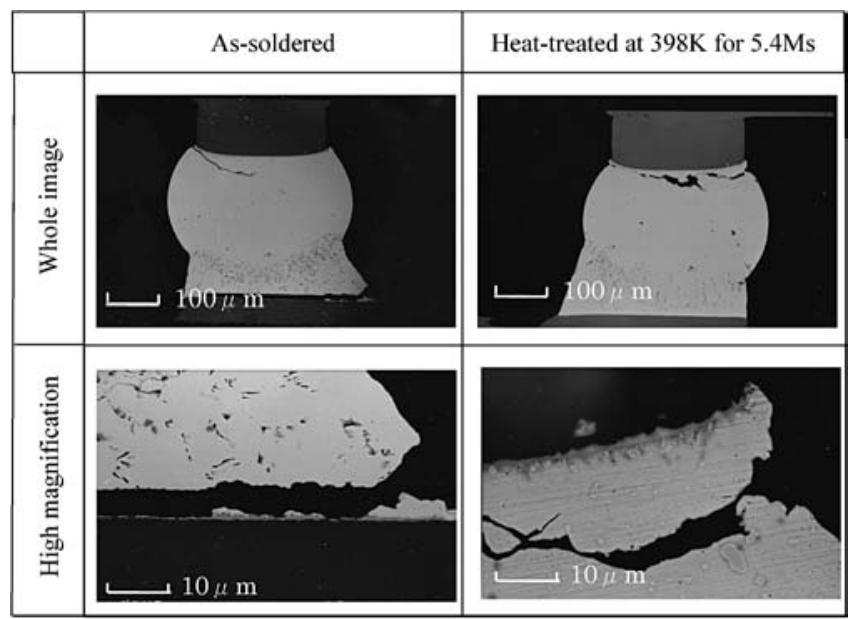

Fig. 13 Crack path of sample SZB-Au0.05-483 after bending fatigue test.
合部の破断経路について Fig. 13 に示す.リフロー直後にお いては，はんだ中および界面反応層での破断の進展の両方が 混在していたが，高温放置後においては，破断ははんだ中で 進展していた．このことから，リフロー直後では $\mathrm{Ni}$ めっき とはんだとの界面強度が十分でなかったものと考えられる。 すなわち，はんだと Ni 界面にリフロー過程の早い段階で形 成する $\mathrm{Au}-\mathrm{Zn}$ 層が，はんだと $\mathrm{Ni}$ の反応を防止するバリア 層として働いたため，界面強度が低く，高温保持によりはん だと Ni の反応が促進され界面強度が向上したと考えられる.

$\mathrm{Ni} / \mathrm{Au}(0.05 \mu \mathrm{m})$ めっき電極で, $503 \mathrm{~K}$ でリフローした接 合部の破断経路について Fig. 14 に示す. $483 \mathrm{~K}$ でリフロー した継手と異なり，リフロー直後および高温放置後のいずれ においても破断ははんだ中で進展していた．このことから， リフロー温度を上昇させ， Ni とはんだ成分が相互拡散し $\mathrm{Ni}-\mathrm{Sn}-\mathrm{Cu}-\mathrm{Zn}$ 層を形成するように界面反応を促進させた方 が，Au-Zn 層が層状に形成した状態よりも，Ni めっきとは んだとの界面強度がより上昇するものと考えられる．

これまでに $\mathrm{Sn}-\mathrm{Ag}$ 系のはんだの接合界面の $\mathrm{Ni}$ めっき層 は，はんだ中の Sn と化合物層を形成する際に消費されるた め，P リッチ層が界面に形成され，その接合信頼性は劣化す ることが知られている ${ }^{9-12)}$ 。この場合も，3.2.2で述べたよ うに接合界面には $\mathrm{P}$ リッチ層が形成していたが，その厚さ が $30 \mathrm{~nm}$ と薄いため $\mathrm{Sn}-\mathrm{Ag}$ 系のはんだのように接合信頼性 への影響はなかったと考えられる.

$\mathrm{Ni} / \mathrm{Au}(0.5 \mu \mathrm{m})$ めっき電極で, $483 \mathrm{~K}$ でリフローした接合 部の破断経路について Fig. 15 に示す。リフロー直後および 高温放置後のいずれにおいても破断は $\mathrm{Au}-\mathrm{Zn}$ と $\mathrm{Ni}$ めっき 界面で進展していた。

$\mathrm{Ni} / \mathrm{Au}(0.5 \mu \mathrm{m})$ めっき電極で, $503 \mathrm{~K}$ でリフローした場合 の破断経路についても $483 \mathrm{~K}$ でリフローした場合と同様， リフロー直後および高温放置後のいずれにおいても破断は $\mathrm{Au}-\mathrm{Zn}$ と Ni めっき界面で進展していた． Au めっき厚さが $0.5 \mu \mathrm{m}$ の場合, いずれも $\mathrm{Au}-\mathrm{Zn}$ と Ni の界面で破断が進展 していることから厚い $\mathrm{Au}-\mathrm{Zn}$ 層と $\mathrm{Ni}$ の界面強度は弱いも のと考えられる．この原因として，Fig. 16 に示すような接

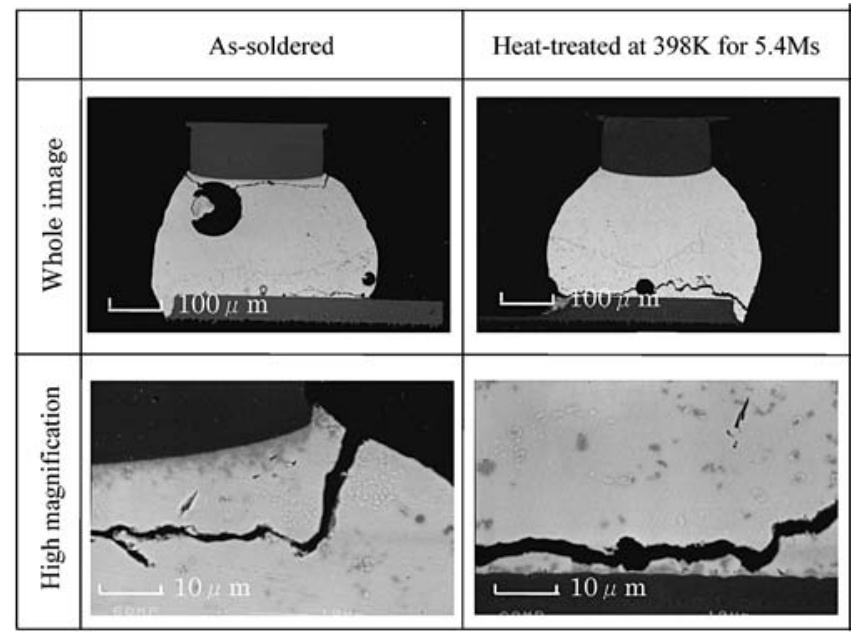

Fig. 14 Crack path of sample SZB-Au0.05-503 after bending fatigue test. 


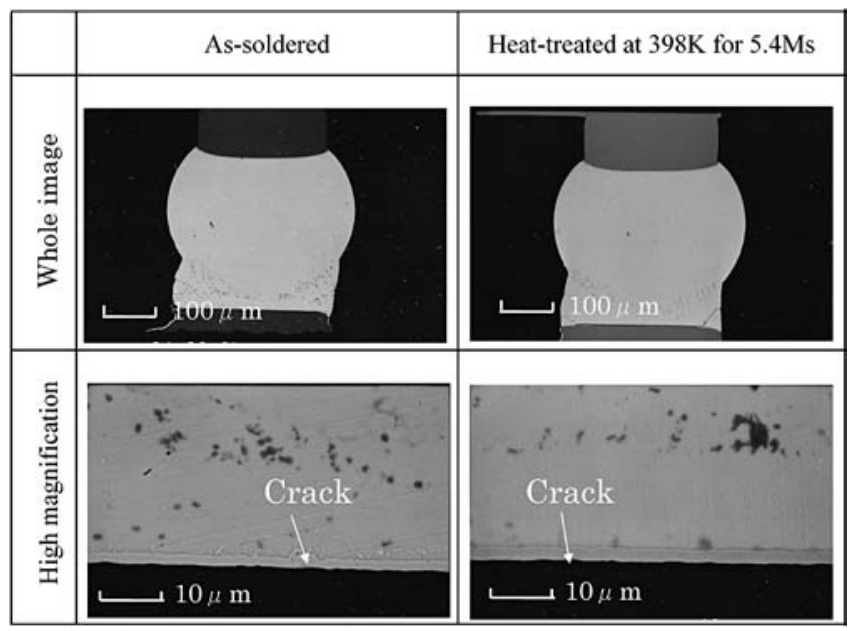

Fig. 15 Crack path of sample SZB-Au0.5-483 after bending fatigue test.

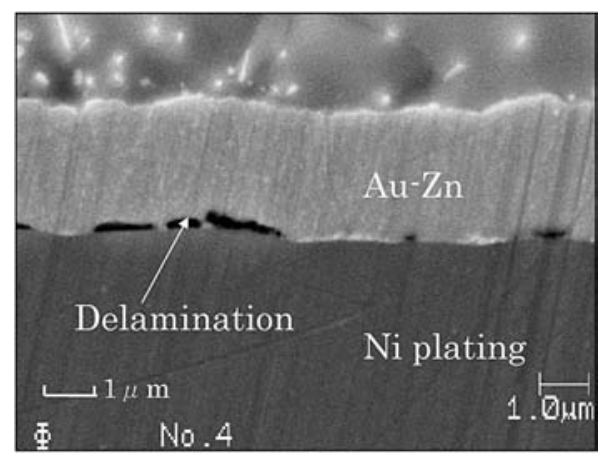

Fig. 16 SE image at interfacial reaction layer of sample SZBAu0.5-503.

合界面に形成した剥離の存在が影響したと考えられる。この ような剥離は， $\mathrm{Au}-\mathrm{Zn}$ 層と $\mathrm{Ni}$ めっきの反応が不十分で界面

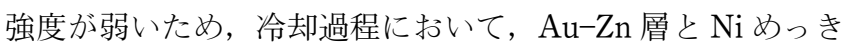
の熱膨張係数の差により界面剥離が生じたものであると考え られる。

以上のようなパッケージレベルの実験結果から，次のよう なことがいえる． $\mathrm{Ni} / \mathrm{Au}$ めっを施さない $\mathrm{Cu}$ 電極の場合は $\mathrm{Cu}-\mathrm{Sn}$ 層の形成による劣化が生じる. そのため, $\mathrm{Ni} / \mathrm{Au}$ め っきを施す必要があり，Auめっきが厚い場合は，その界面 強度が弱いため, $\mathrm{Au}$ めっを $0.05 \mu \mathrm{m}$ 程度に薄く施すこと が適当であると考えられる。 また，リフローピーク温度につ いてはリフロー温度を上昇させ界面反応を進行させるほうが より優れた継手特性を有するものと考えられる.

このように, $\mathrm{Sn}-8 \mathrm{Zn}-3 \mathrm{Bi}$ はんだの接合信頼性は基板電極 との間に形成する界面反応層の影響を受け，リフローピーク 温度は，この界面反応層に影響を与えることが明らかになっ た．そこで，適正リフロープロファイルを明らかにするた め，リフローピーク温度を細かく変化させ，リフローピーク 温度が界面反応と継手強度に及ぼす影響について，さらに詳 細に検討した。

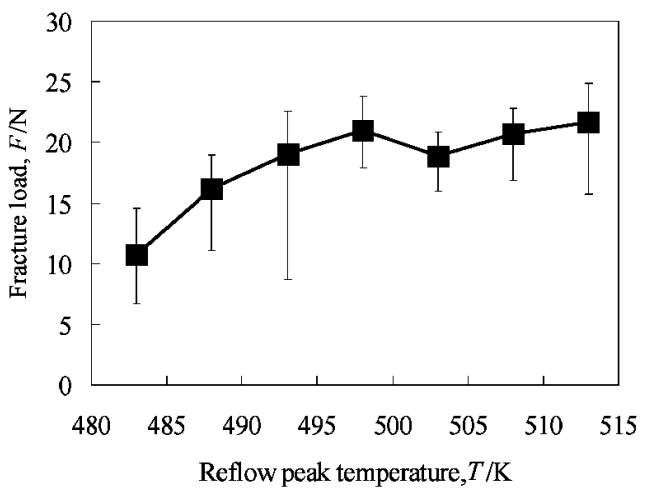

Fig. 17 Influence of the reflow peak temperature on joint strength on $\mathrm{Ni} / \mathrm{Au}$ plating pad with Au plating of $0.05 \mu \mathrm{m}$ thickness using $\mathrm{Sn}-8 \mathrm{Zn}-3 \mathrm{Bi}$ solder and $\mathrm{Sn}-3 \mathrm{Ag}-0.5 \mathrm{Cu}$ solder ball.

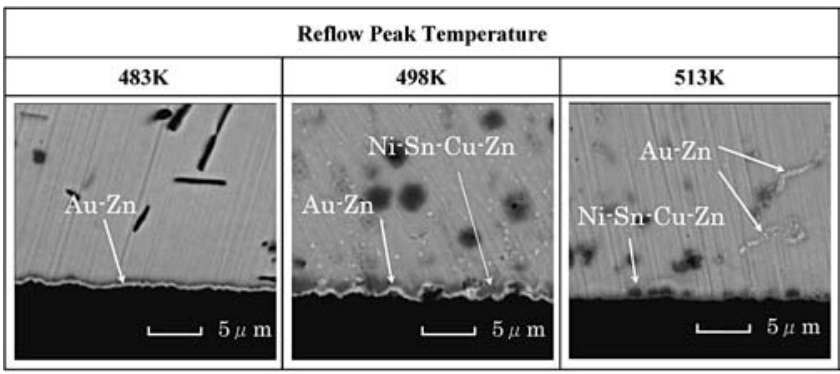

Fig. 18 Interfacial reaction layer of joints on $\mathrm{Ni} / \mathrm{Au}$ plating pad with $\mathrm{Au}$ plating of $0.05 \mu \mathrm{m}$ thickness soldered at various temperature using $\mathrm{Sn}-8 \mathrm{Zn}-3 \mathrm{Bi}$ solder and $\mathrm{Sn}-3 \mathrm{Ag}-0.5 \mathrm{Cu}$ solder ball.

\section{4 適正リフロープロファイル}

パッケージレベルの評価と同じはんだボールおよびはんだ ペーストを用い, $\mathrm{Ni}(5 \mu \mathrm{m}) / \mathrm{Au}(0.05 \mu \mathrm{m})$ めっき電極を用い て，ボール接合部単点強度評価を行った。リフロー条件は接 合強度および界面反応に及ぼす影響を詳細に検討するため, $483 \mathrm{~K}$ から $513 \mathrm{~K}$ の間で $5 \mathrm{~K}$ 刻みに变化させた。 また強度 試験方法として, 界面強度の影響が出やすい加熱式バンププ ル試験で行った.

\subsection{1 リフローピーク温度と接合強度}

Fig. 17 にリフローピーク温度と接合強度の関係を示す. この結果から, リフローピーク温度の上昇とともに接合強度 の上昇が認められた。 なお， $498 \mathrm{~K}$ 以上のピーク温度では大 きな変化はなかった。

\subsection{2 リフローピーク温度と界面組織}

Fig. 18 にリフローピーク温度と接合部組織の変化を示 す。この組織観察結果から, CSP パッケージレベルの評価 で述べたのと同様，リフローピーク温度が上昇するに従い, $\mathrm{Au}-\mathrm{Zn}$ 層がはんだ中へと溶解・拡散している様子が観察さ れた.リフローピーク温度が $513 \mathrm{~K}$ になると完全に $\mathrm{Au}-\mathrm{Zn}$ 層は界面から消失していた。

これらのことからリフローピーク温度を $483 \mathrm{~K}$ 以上に し, 界面に $\mathrm{Ni}-\mathrm{Sn}-\mathrm{Cu}-\mathrm{Zn}$ を形成させることで十分な継手強 度が得られるようになると言える。そのため，はんだ付けプ ロセスの低温化が可能な $\mathrm{Sn}-8 \mathrm{Zn}-3 \mathrm{Bi}$ はんだの接合特性を最 
大限引き出すためには, $498 \mathrm{~K}$ 程度のリフローピーク温度を もつリフロープロファイルで実装することが適正であると言 える.

\section{4. 結 言}

本研究では, $\mathrm{Sn}-8 \mathrm{Zn}-3 \mathrm{Bi}$ はんだペーストを用いて, Ni/ $\mathrm{Au}$ めっき電極上に実装した CSP 接合部において，リフ ローピーク温度が接合信頼性に与える影響について, 界面組 織と継手特性から検討を行った。本研究で得られた主な結論 は，以下の通りである。

1） Sn-8Zn-3Bi はんだを用いたはんだ付けにおいて， $\mathrm{Cu}$ 電極を用いた接合部については，界面に厚い $\mathrm{Cu}-\mathrm{Zn}$ 層と $\mathrm{Cu}-\mathrm{Sn}$ 層を形成するため，接合信頼性を低下させる，その

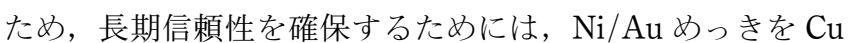
電極に施す必要がある。

2) $\mathrm{Ni} / \mathrm{Au}$ めっき電極で， $\mathrm{Au}$ めっき厚が $0.05 \mu \mathrm{m}$ の場 合，その接合界面には $\mathrm{Au}-\mathrm{Zn}$ 層が形成する．この $\mathrm{Au}-\mathrm{Zn}$ 層 は，リフローピーク温度を上げていくと，はんだ中に溶解 · 拡散し，界面には $\mathrm{Ni}-\mathrm{Sn}-\mathrm{Cu}-\mathrm{Zn}$ 層が形成する。この界面反 応層は，はんだと Ni めっきとの界面強度を向上させ，接合 信頼性を改善させる。

3) $\mathrm{Ni} / \mathrm{Au}$ めっき電極で, $\mathrm{Au}$ めっき厚が $0.5 \mu \mathrm{m}$ の場 合，接合界面に剥離が起こり， $\mathrm{Au}-\mathrm{Zn}$ 層と $\mathrm{Ni}$ との界面強度 は低下する

4） $\mathrm{Sn}-8 \mathrm{Zn}-3 \mathrm{Bi}$ はんだと $\mathrm{Ni} / \mathrm{Au}$ めっ電極を用いた CSP 接合部の信頼性は基板電極との間に形成する界面反応 層の影響を受け，リフローピーク温度は，この界面反応層に 影響を与える。リフローピーク温度を上昇させ界面に $\mathrm{Ni}-$
$\mathrm{Sn}-\mathrm{Cu}-\mathrm{Zn}$ を形成させることにより接合強度が上昇し，リフ ローピーク温度が $498 \mathrm{~K}$ で接合強度が最大となる。

5）はんだ付けプロセスの低温化が可能な Sn-8Zn-3Bi は んだによる CSP 実装においては， Ni/Auめっき電極を用 い，その $\mathrm{Au}$ めっき厚を $0.05 \mu \mathrm{m}$ とし，リフローピーク温度 を $498 \mathrm{~K}$ とすることで高い接合信頼性を確保できる.

\section{文献}

1) K. Nishi: J. Japan Inst. Electronics Packaging 4(2001) pp. 2225.

2) K. Suganuma: Current Opinion in Solid State \& Material Science 5(2001) 55-64.

3) M. Abtew and G. Selvanduray: Mater. Sci. Eng. 27 (2000) 95141

4) H. Iwanishi, T. Imamura, A. Hirose and K. F. Kobayashi: Proc. 8th Symposium on Microjoining and Assembly Technology in Electronics, (The Japan Welding Society, 2002) pp. 277-282.

5) A. Yamaguchi, A. Furusawa, H. Otani, J. Ikeda, H. Iwanishi, T. Hojo, A. Hirose and K. F. Kobayashi: Proc. 8th Symposium on Microjoining and Assembly Technology in Electronics, (The Japan Welding Society, 2002) pp. 295-300.

6) A. Yamaguchi, H. Iwanishi, T. Hojo, A. Hirose and K. F. Kobayashi: 8th Pan Pacific Microelectronics symposium, (SMTA, 2003) pp. 87-93

7) T. Takahashi, K. Toyofuku, H. Iida and K. Yamamoto: Proc.12th Symposium on Microelectronics Symposium, (Japan Inst. Electronics Packaging, 2002) pp. 175-178.

8) K. Suganuma, K. Nishihara, T. Shoutoku and Y. Nakamura: J. Mater. Res. 13(1998) 2859-2865.

9) S. Sakatani, Y. Kohara, T. Saeki, K. Uenishi and K. F. Kobayashi: Proc.12th Symposium on Microelectronics Symposium, (Japan Inst. Electronics Packaging, 2002) pp. 127-130.

10) K. Uenishi, Y. Kohara, S. Sakatani and K. F. Kobayashi: 9th Symposium on Microjoining and Assembly Technology in Electronics, (The Japan Welding Society, 2003) pp. 127-130.

11) S. J. Wang and C. Y. Liu: Scr. Mater. 49(2003) 813-818.

12) H. Matsuki, H. Ibuka and H. Saka: Sci. Tech. Adv. Mater. 3(2002) 261-270. 